\title{
Whole-exome sequencing in 16,511 individuals reveals a role of the HTRA1 protease and its substrate EGFL8 in brain white matter hyperintensities
}

\section{Rainer Malik ${ }^{1 *}$, Nathalie Beaufort ${ }^{1^{*}}$, Simon Frerich ${ }^{1}$, Benno Gesierich ${ }^{1}$, Marios K Georgakis $^{1}$, Kristiina Rannikmäe ${ }^{2}$, Amy C Ferguson ${ }^{2}$, Christof Haffner ${ }^{1}$, Matthew Traylor $^{3,4}$, Michael Ehrmann ${ }^{5,6}$, Cathie LM Sudlow ${ }^{2,7,8}$, Martin Dichgans ${ }^{1,9,10}$}

${ }^{1}$ Institute for Stroke and Dementia Research (ISD), University Hospital, LMU Munich, Munich, Germany

${ }^{2}$ Centre for Medical Informatics, Usher Institute, University of Edinburgh, Edinburgh, UK

${ }^{3}$ Clinical Pharmacology, William Harvey Research Institute, Queen Mary University of London, London, UK

${ }^{4}$ The Barts Heart Centre and NIHR Barts Biomedical Research Centre - Barts Health NHS Trust, The William Harvey Research Institute, Queen Mary University of London, London, UK

${ }^{5}$ Center of Medical Biotechnology, Faculty of Biology, University Duisburg-Essen, Essen, Germany

${ }^{6}$ School of Biosciences, Cardiff University, Cardiff, UK

${ }^{7}$ Centre for Clinical Brain Sciences, University of Edinburgh, Edinburgh, UK

${ }^{8}$ Health Data Research UK Scotland, University of Edinburgh, Edinburgh, UK

${ }^{9}$ Munich Cluster for Systems Neurology, Munich, Germany

${ }^{10}$ German Center for Neurodegenerative Diseases (DZNE), Munich, Germany

* These authors contributed equally

Correspondence should be addressed to:

Prof. Martin Dichgans

Institute for Stroke and Dementia Research (ISD)

Feodor-Lynen-Str. 17

81377 München

Germany

M: Martin.dichgans@med.uni-muenchen.de

$P:+49-89-4400-46018$

Word count: 5,888

Figures: 5

Tables: 3 
medRxiv preprint doi: https://doi.org/10.1101/2021.03.26.21253954; this version posted March 29, 2021. The copyright holder for this preprint (which was not certified by peer review) is the author/funder, who has granted medRxiv a license to display the preprint in perpetuity.

It is made available under a CC-BY-NC-ND 4.0 International license .

\section{ABSTRACT}

White matter hyperintensities $(\mathrm{WMH})$ are among the most common radiological abnormalities in the ageing population and an established risk factor for stroke and dementia. While common variant association studies have revealed multiple genetic loci with an influence on $\mathrm{WMH}$ volume, the contribution of rare variants to $\mathrm{WMH}$ burden in the general population remains largely unexplored. We conducted a comprehensive analysis of WMH burden in the UK Biobank using publicly available whole-exome sequencing data $(\mathrm{N}=16,511)$ and found a splice-site variant in $G B E 1$, encoding 1,4-alpha-glucan branching enzyme 1, to be associated with lower white matter burden on an exome-wide level (c.691+2T>C, beta=-0.74, se=0.13, p=9.7E9). Applying whole-exome gene-based burden tests, we found damaging missense and loss-of-function variants in HTRA1 to associate with increased WMH volume $(\mathrm{p}=5.5 \mathrm{E}-6, \mathrm{FDR}=0.04)$. HTRA1 encodes a secreted serine protease implicated in familial forms of small vessel disease. Domain-specific burden tests revealed that the association with $\mathrm{WMH}$ volume was restricted to rare variants in the protease domain (amino acids 204-364; beta=0.79, se=0.14, $p=9.4 \mathrm{E}-8$ ). The frequency of such variants in the UK Biobank population was 1 in 450 . WMH volume was brought forward by approximately 11 years in carriers of a rare protease domain variant. $A$ comparison with the effect size of established risk factors for $\mathrm{WMH}$ burden revealed that the presence of a rare variant in the HTRA1 protease domain corresponded to a larger effect than meeting the criteria for hypertension (beta=0.26, se $=0.02, p=2.9 E$ 59 ) or being in the upper $99.8 \%$ percentile of the distribution of a polygenic risk score based on common genetic variants (beta=0.44, se $=0.14, p=0.002$ ). In biochemical experiments, most (6/9) of the identified protease domain variants resulted in a markedly reduced protease activity. We further found EGFL8, which showed suggestive evidence for association with $\mathrm{WMH}$ volume $(p=1.5 \mathrm{E}-4, \mathrm{FDR}=0.22)$ in gene burden tests, to be a direct substrate of HTRA1 and to be preferentially expressed in cerebral arterioles and arteries. In a phenome-wide association study (PheWAS) mapping ICD-10 diagnoses to 741 standardized Phecodes, rare variants in the HTRA1 protease domain were associated with multiple neurological and nonneurological conditions including migraine with aura $(\mathrm{OR}=12.24,95 \% \mathrm{Cl}$ [2.54-35.25], $\mathrm{p}=8.3 \mathrm{E}-5)$. Collectively, these findings highlight an important role of rare genetic variation and of the HTRA1 protease in determining $\mathrm{WMH}$ burden in the general population. 
medRxiv preprint doi: https://doi.org/10.1101/2021.03.26.21253954; this version posted March 29, 2021. The copyright holder for this preprint (which was not certified by peer review) is the author/funder, who has granted medRxiv a license to display the preprint in perpetuity.

It is made available under a CC-BY-NC-ND 4.0 International license .

\section{INTRODUCTION}

White matter hyperintensities (WMH) are common in elderly individuals (Garde et al., 2000; Debette and Markus, 2010) and an increasingly recognized risk factor for stroke (Wardlaw et al., 2013; Debette et al., 2019), dementia (Wardlaw et al., 2013; Dichgans and Leys, 2017; Debette et al., 2019), and functional decline in the older age (Ladis Study Group, 2011). They are further associated with poor long-term outcomes after ischemic stroke including an increased risk of stroke recurrence, dementia, and mortality (Georgakis et al., 2019). While not specific for any particular etiology, WMH are considered a marker of cerebral small vessel disease (SVD) (Dichgans and Leys, 2017; Wardlaw et al., 2019). Hypertension is the single strongest treatable risk factor for WMH (Dufouil et al., 2001; Wardlaw et al., 2013; Georgakis et al., 2019). However, the precise mechanisms underlying WMH remain largely elusive.

WMH are highly heritable with estimates ranging from 18-54\% (Duperron et al., 2018; Persyn et al., 2020). Accordingly, recent genome-wide association studies (GWAS) found common genetic variants at multiple loci to be associated with $\mathrm{WMH}$ burden (Fornage et al., 2011; Armstrong et al., 2020; Persyn et al., 2020; Sargurupremraj et al., 2020). Besides confirming a causal link with hypertension (Sargurupremraj et al., 2020) these studies also pinpoint specific molecular pathways and biological mechanisms. Among the most prominent themes are perturbations of the extracellular matrix (ECM) as evidenced by associations at loci that encode matrisome proteins. These loci include COL4A2 (encoding collagen type IV alpha 2 chain), EFEMP1 (encoding EGF containing fibulin extracellular matrix protein 1), VCAN (encoding versican), and NID2 (encoding nidogen). Additional themes, that have emerged from recent GWAS, include dysfunction of vascular endothelial and mural cells, the blood-brain barrier, and inflammatory mechanisms (Neurology Working Group of the Cohorts for Heart Aging Research in Genomic Epidemiology Consortium et al., 2016; Persyn et al., 2020; Sargurupremraj et al., 2020). The results from recent GWAS on WMH further highlight links with small vessel stroke, ischemic stroke, intracerebral hemorrhage, and neurodegenerative disease (Malik et al., 2018; Sargurupremraj et al., 2020; Traylor et al., 2021). As such, large scale genetic studies have been instrumental in uncovering core pathways and mechanisms 
medRxiv preprint doi: https://doi.org/10.1101/2021.03.26.21253954; this version posted March 29, 2021. The copyright holder for this preprint (which was not certified by peer review) is the author/funder, who has granted medRxiv a license to display the preprint in perpetuity.

It is made available under a CC-BY-NC-ND 4.0 International license .

underlying $\mathrm{WMH}$ and defining relationships with related phenotypes, in particular SVD.

A close link between WMH and SVD is further supported by observations in familial forms of SVD (Dichgans et al., 2019). WMH are a regular feature in carriers of a pathogenic mutation in NOTCH3 (encoding neurogenic locus notch homolog protein 3), the gene implicated in cerebral autosomal dominant arteriopathy with subcortical infarcts and leukoencephalopathy (CADASIL) (Joutel et al., 1996; Dichgans et al., 1998). They are further seen in patients with cerebral autosomal recessive arteriopathy with subcortical infarcts and leukoencephalopathy (CARASIL), a severe type of SVD caused by homozygous or bi-allelic HTRA1 mutations (Hara et al., 2009). HTRA1 encodes a secreted serine protease that associates with the ECM and has been shown to proteolytically process various molecular constituents of the ECM including latent TGF-ß binding protein, vitronectin, and elastin (Beaufort et al., 2014). The outstanding importance of perturbations of the ECM in the pathophysiology of $\mathrm{WMH}$ is further illustrated by highly penetrant mutations in COL4A1 and COL4A2 (Gould et al., 2006; Verdura et al., 2016; Jeanne and Gould, 2017). These mutations cause a broad range of phenotypes including $\mathrm{WMH}$, small vessel stroke, intracerebral hemorrhage, porencephalopathy, and extracerebral manifestations (Verdura et al., 2016; Jeanne and Gould, 2017). Notably, extracerebral manifestations such as ocular and renal manifestations are a common feature in various forms of hereditary SVD (Rannikmae et al., 2020).

While the above studies have contributed to the understanding of common genetic variation in $\mathrm{WMH}$ and the role of highly penetrant mutations in familial SVD, the significance of rare genetic variation for $\mathrm{WMH}$ in the general population remains largely unexplored. To the best of our knowledge, previous studies focused on variants included on HumanExome BeadChip arrays (Jian et al., 2018) and on genes implicated in familial SVD (Mishra et al., 2019; Rutten et al., 2020; Cho et al., 2021). Of note, some of them included samples that had been selected on the basis of extreme phenotypes (Mishra et al., 2019).

The UK Biobank (UKB) (Bycroft et al., 2018) is a large-scale ( 500.000 participants) prospective community-based study that recruited from the general midlife population aged between 40 and 69 years and offers phenotypic information on multiple traits including brain imaging with quantitative data on $\mathrm{WMH}$ volumes available in about 
medRxiv preprint doi: https://doi.org/10.1101/2021.03.26.21253954; this version posted March 29, 2021. The copyright holder for this preprint (which was not certified by peer review) is the author/funder, who has granted medRxiv a license to display the preprint in perpetuity.

It is made available under a CC-BY-NC-ND 4.0 International license .

44,000 individuals (Littlejohns et al., 2020). The UKB further offers detailed clinical information mapped to international classification of diseases (ICD-10) codes, genome-wide genotyping of single nucleotide polymorphisms (SNPs), and as of recently, whole-exome sequencing (WES) data. In contrast to genome-wide genotyping, WES enables comprehensive analysis of all genetic variation in coding regions, including rare variants that have previously been inaccessible. In many complex traits and diseases, studying to this variation has contributed to understanding their genetic basis (Flannick et al., 2019; Jurgens et al., 2020; Wang et al., 2020).

Here, we leveraged data from the UKB to systemically investigate associations between rare variation and $\mathrm{WMH}$ burden in a population-based setting. Specifically, we set out to: i) identify single variants associated with $\mathrm{WMH}$ burden at an exomewide level, ii) identify genes associated with WMH load in burden tests, iii) experimentally determine the functional consequences of selected variants; iv) identify genes implicated in pathways and interaction networks relevant to SVD; and v) explore the phenotypic spectrum of alternative allele carriers in a phenome-wide association study (PheWAS). 
medRxiv preprint doi: https://doi.org/10.1101/2021.03.26.21253954; this version posted March 29, 2021. The copyright holder for this preprint (which was not certified by peer review) is the author/funder, who has granted medRxiv a license to display the preprint in perpetuity.

It is made available under a CC-BY-NC-ND 4.0 International license .

\section{MATERIALS AND METHODS}

This analysis was carried out under the UKB project 2532.

\section{UK Biobank population}

Our resource was the UK Biobank Exome 200k release from October 2020. Primary and secondary analyses were performed with an updated Functional Equivalence (FE) protocol that retains original quality scores in the CRAM files (referred to as the OQFE protocol) (Szustakowski et al., 2020).

The 200k release encompasses 1,135 parent-offspring pairs, 3,855 full-sibling pairs, including 101 trios, 27 monozygotic twin pair and 7,461 second degree genetically determined relationships. To avoid bias due to relatedness, we selected an unrelated set of individuals up to a $2^{\text {nd }}$ degree (KING cut-off 0.0877) (Manichaikul et al., 2010). For the $\mathrm{WMH}$ volume analysis, we preferentially retained individuals with more extreme trait values (i.e. further away from the mean) in the analysis using PRIMUS (Staples et al., 2014). For PheWAS analyses, we selected a standard unrelated set (also up to a $2^{\text {nd }}$ degree) which was used for all subsequent analyses ( $\left.N=166,897\right)$. We further excluded individuals showing an excess of heterozygosity from the UK Biobank genotyping analysis and individuals of non-White British ancestry.

For the WMH analyses we used UKB field ID 25781 ( $N=38,347$; N with WES=17,830; $\mathrm{N}$ unrelated=16,511). This study used the January 2020 release of UK Biobank imaging data on approximately 44,000 individuals. MRI was performed on two identical Siemens Skyra 3.0 T scanners (Siemens Medical Solutions, Germany), running VD13A SP4, with a standard Siemens 32-channel RF receiver head coil. Identical acquisition parameters and detailed quality control was used for all scans. Using the T2-FLAIR sequence, WMH volumes were generated by an imageprocessing pipeline developed and run on behalf of UKB and were available as part of the UK Biobank central analysis (https://biobank.ctsu.ox.ac.uk/crystal/crystal/docs/brain mri.pdf) (Griffanti et al., 2016; Miller et al., 2016; Alfaro-Almagro et al., 2018). We excluded three extreme volume outliers (>6SD) and used log-transformed $\mathrm{WMH}$ volume to ensure normal distribution.

\section{Single Variant analysis}


medRxiv preprint doi: https://doi.org/10.1101/2021.03.26.21253954; this version posted March 29, 2021. The copyright holder for this preprint (which was not certified by peer review) is the author/funder, who has granted medRxiv a license to display the preprint in perpetuity.

It is made available under a CC-BY-NC-ND 4.0 International license .

Single variant analysis of rare variants in the WES data was done using REGENIE (Mbatchou et al., 2020). REGENIE accounts for relatedness and subtle population stratification through a mixed-model approach. The mixed model parameters were estimated using 200,000 genotyped common variants. Saddle point approximation (SPA) regression was used in favor of Firth's correction due to performance issues. We set a conservative exome-wide threshold of 5E-8 as significance cut-off in our analysis.

\section{Whole-exome burden test on white matter hyperintensities (WMH)}

We determined the functional consequences of exome-wide variants using the Variant Effect Predictor (VEP) tool v101 (McLaren et al., 2016). For the whole-exome burden test on $\mathrm{WMH}$ analysis, we selected rare variants (MAF < 0.01) that are either predicted to be damaging by REVEL (loannidis et al., 2016) (REVEL score > 0.5) or predicted to exert a high-confidence loss-of-function effect using the LoFTEE (Karczewski et al., 2020) plugin in VEP.

For the domain specific analyses of HTRA1, we extracted all missense variants according to their position in the domain structure as defined by Uniprot identifier Q92743 (UniProt Consortium, 2019): signal peptide domain (Amino Acids [AA] 1-22), IGFBP domain (AA 33-100), Kazal-like domain (AA 100-157), Protease domain (AA 204-364) and PDZ domain (AA 365-467).

Whole-exome burden test were done using rvtests (Zhan et al., 2016) and by calculating multivariable burden tests using the CMC burden schema (Lee et al., 2014). Sex, age at imaging and 10 genomic principal components (PCs) were used as covariates in all analyses. For the primary logWMH analysis, we additionally corrected for vascular risk factors (SBP, LDL, BMI, Hba1C) in a sensitivity analysis. Results were deemed significant at an FDR level of $5 \%$ after FDR correction. To estimate effect sizes and standard errors, we used linear regression with minor allele carrier status as a dependent variable and age at imaging, sex and 10 genomic PCs as covariates.

To compare effect sizes to dichotomised risk factors for $\mathrm{WMH}$, we extracted the following information from the UKB: hypertension status (yes/no), defined as a systolic blood pressure (SBP) $>140 \mathrm{mmHg}$ or a diastolic blood pressure (DBP) $>90 \mathrm{mmHg}$ (UKB fields 4080 and 4079 ) taking the mean of available measurements 
medRxiv preprint doi: https://doi.org/10.1101/2021.03.26.21253954; this version posted March 29, 2021. The copyright holder for this preprint (which was not certified by peer review) is the author/funder, who has granted medRxiv a license to display the preprint in perpetuity. It is made available under a CC-BY-NC-ND 4.0 International license .

and correcting SBP and DBP for antihypertensive drug use (UKB field 2003) as appropriate; diabetes mellitus (yes/no, UKB field 2443); BMI (above mean vs. below mean; UKB field 21001); smoking (ever smoked vs never smoked; UKB field 20116). We further calculated a polygenic risk score (PRS) based on common genetic variants from the most recent WMH GWAS (Sargurupremraj et al., 2020). Specifically, we selected the 27 genome-wide significant lead SNPs and constructed a weighted allelic risk score for each individual in our dataset. Variants were weighted by their respective effect sizes in their association with $\mathrm{WMH}$. We compared individuals above the mean vs below the mean, with a PRS >95\% percentile vs PRS $<95 \%$ percentile, and a PRS $>99.8 \%$ percentile vs $\mathrm{PRS}<99.8 \%$ percentile. The cutoff of $99.8 \%$ was chosen to achieve the same case number as for the HTRA1 protease domain variant carrier status. Thus, the standard error is identical.

\section{Recombinant protein expression}

Expression vectors. The cDNA encoding human full-length HTRA1 (AA 1-480) or human full-length EGFL8 (AA 1-293, Origene) were cloned into a pcDNA4/TO/mycHis expression plasmid (Invitrogen). The cDNA encoding the $\mathrm{N}$-terminal region of human LTBP1 (Latent-transforming growth factor beta-binding protein 1, AA 1-689) fused to a C-terminal V5-His tag was cloned into the pTT5 plasmid. Mutagenesis was conducted using the QuickChange Lightning Site-Directed Mutagenesis kit (Agilent Technologies).

Cell culture and transfection. Human embryonic kidney (HEK) 293E cells were grown in Dulbecco's modified Eagle's medium (DMEM) containing GlutaMAX, 10\% (v/v) fetal calf serum (FCS), $100 \mathrm{U} / \mathrm{ml}$ penicillin and $100 \mu \mathrm{g} / \mathrm{ml}$ streptomycin (all from Invitrogen). Cells were transfected with Lipofectamine 2000 (Invitrogen) and maintained for $48 \mathrm{~h}$ in FCS-free DMEM before culture medium was collected and centrifuged for $10 \mathrm{~min}$ at $400 \mathrm{~g}$ to remove debris.

EGFL8 enrichment. Stably transfected HEK cells were selected using Zeocin (100 $\mu \mathrm{g} / \mathrm{ml}$, Invitrogen), then maintained in FCS-free DMEM for 4-5 days. Culture medium was collected and centrifuged at $1,000 \mathrm{~g}$ for $15 \mathrm{~min}$, dialyzed at room temperature against $0.5 \times$ phosphate-buffered saline (PBS) for $2 \mathrm{~h}$ and overnight at $4^{\circ} \mathrm{C}$ against 0.5 x PBS containing $200 \mathrm{mM} \mathrm{NaCl}$. Medium was gently agitated for $1 \mathrm{~h}$ at room temperature in the presence of Talon resin ( $5 \mu$ l solution per $\mathrm{ml}$ medium, Clontech) and the resin subsequently transferred to a gravity flow column. After washes, 
medRxiv preprint doi: https://doi.org/10.1101/2021.03.26.21253954; this version posted March 29, 2021. The copyright holder for this preprint (which was not certified by peer review) is the author/funder, who has granted medRxiv a license to display the preprint in perpetuity.

It is made available under a CC-BY-NC-ND 4.0 International license .

EGFL8 was eluted with $100 \mathrm{mM}$ EDTA in PBS and the eluate dialyzed overnight at $4^{\circ} \mathrm{C}$ against 1,000 volume of Tris $50 \mathrm{mM}, \mathrm{NaCl} 150 \mathrm{mM}, \mathrm{pH} 8.0$.

HTRA1 purification. Human HTRA1 wild type (wt) lacking the N-terminal Mac domain (AA 158-480) was produced as described previously (Poepsel et al., 2015) with small modifications. N-termnially Strepll-tagged wt HTRA1 was affinity-purified with a streptactin resin material (IBA lifescieces) and subsequently subjected to size exclusion chromatography using a Superdex 200 preparation grade column (GE Healthcare) in 20 mM HEPES, 50 mM NaCl, pH 7.5.

\section{Protease activity assays}

Medium from HEK cells overexpressing LTBP1 was treated with medium from cells overexpressing HTRA1 for $24 \mathrm{~h}$ at $37^{\circ} \mathrm{C}$. LTBP1 proteolysis was evaluated by anti-V5 immunoblot. Relative protease activity was calculated as the ratio of cleaved tointact LTBP1 and was normalized to HTRA1 expression, assessed by anti-Myc immunoblot.

EGFL8 was treated with 100 or $500 \mathrm{nM}$ purified wt HTRA1 for $24 \mathrm{~h}$ at $37^{\circ} \mathrm{C}$. Where indicated, $5 \mu \mathrm{M}$ of the HTRA1 inhibitor NVP-LBG976 (obtained from Novartis Pharmaceuticals) were added to the reaction (Grau et al., 2005). Substrate proteolysis was assessed by anti-Myc (EGFL8) immunoblot

\section{SDS-PAGE and immunoblot}

Proteins were separated by SDS-PAGE and transferred onto polyvinylidene difluoride membranes (Immobilon-P, Millipore). Membranes were blocked in Tris-buffered saline (TBS) containing $0.2 \%(\mathrm{v} / \mathrm{v})$ Tween 20 and 4\% (w/v) skim milk and probed with anti-Myc (Santa Cruz Biotechnology, \#sc-40, 1:5,000), anti-V5 (Invitrogen, \#R960-25, 1:10,000) or anti-HTRA1 (R\&D Systems, \#MAB2916, 1:5,000) primary antibodies prepared in TBS/Tween/milk. Detection was performed with Horseradish peroxidase (HRP)-coupled secondary antibodies (Dako), Immobilon Western kit reagents (Millipore) and the Fusion FX7 documentation system (Vilbert Lourmat). Signal intensity was quantified with ImageJ.

\section{Immunohistochemistry}

Frozen human brain (frontal subcortex) from a 55-year-old individual with no known cerebrovascular disorder was provided by the Brain-Net Europe Biobank (Ludwig- 
medRxiv preprint doi: https://doi.org/10.1101/2021.03.26.21253954; this version posted March 29, 2021. The copyright holder for this preprint (which was not certified by peer review) is the author/funder, who has granted medRxiv a license to display the preprint in perpetuity.

It is made available under a CC-BY-NC-ND 4.0 International license .

Maximilians-University Munich) and analyzed according to the guidelines of the local ethical committees. For EGFL8 detection, ten $\mu \mathrm{m}$ tissue sections were thawed to room temperature (RT) and fixed for $20 \mathrm{~min}$ in $4 \%(\mathrm{w} / \mathrm{v})$ paraformaldehyde then permeabilized and blocked in PBS added with 0.1\% (v/v) Triton-X100 and 5\% (w/v) bovine serum albumin (BSA) for $1 \mathrm{~h}$ at RT. Primary antibodies were diluted in PBS/Triton/BSA or PBS/BSA as follows: anti-EGFL8 Ab (Sigma-Aldrich, \#HPA061173, 1:50), anti-collagen IV Ab (SouthernBiotech, \#1340-01, 1:200), Cy3coupled anti- $\alpha$ smooth muscle actin (SMA) Ab (Merck, \#C6198, 1:100) and incubation was performed overnight at $4^{\circ} \mathrm{C}$. Following washing with PBS, sections were incubated with Alexa Fluor 488- or 647-coupled secondary antibodies (Abcam, 1:100) and 4',6-Diamidin-2-phenylindol (DAPI, ThermoFisher Scientific) diluted in PBS for $1 \mathrm{~h}$ at RT. Tissue was washed, mounted with Fluoromount (Sigma-Aldrich), and images captured by confocal microscopy (LSM800, Zeiss).

\section{PheWAS}

To explore the association of specific regions and variants in the full range of phenotypes encoded within the UK Biobank, we used the Phecode Map 1.2 to map UKB ICD10-codes to Phecodes (Wu et al., 2019). We used all ICD10 codes (main position, secondary position, death records) from the UKB. We excluded Phecodes with $<100$ cases and Phecodes that are male- or female-specific. Individuals were assigned a case status if $>1$ ICD10 code mapped to the respective Phecode. Individuals meeting the pre-specified exclusion criteria were removed from the analysis, otherwise the individual was assigned a control status. Given the known association between white matter hyperintensities and stroke, we further analyzed any stroke (AS), any ischemic stroke (AIS) and intracerebral hemorrhage (ICH) as defined by the algorithmically defined stroke outcomes (UKB fields 42006-42013). Results were deemed significant at an FDR level of $5 \%$ after FDR correction. To approximate effect size in a logistic regression framework, we used minor allele carrier status as an independent variable and age at baseline, sex and 10 genomic PCs as covariates. We used Firth's correction for unbalanced case/control ratios in our logistic regression analysis. 
medRxiv preprint doi: https://doi.org/10.1101/2021.03.26.21253954; this version posted March 29, 2021. The copyright holder for this preprint (which was not certified by peer review) is the author/funder, who has granted medRxiv a license to display the preprint in perpetuity.

It is made available under a CC-BY-NC-ND 4.0 International license .

\section{RESULTS}

We analyzed up to 17,830 individuals from the UK Biobank with both WES data and quantitative data on WMH volume available. Their demographic characteristics are presented in Supp Table 1.

\section{A predicted splice donor loss-of-function variant in GBE1 associates with WMH volume}

In the single variant analysis using a mixed model approach and correcting for sex, age at imaging, and 10 principal components (PCs), we found one rare variant (MAF $<0.01)$ to be associated at genome-wide significance level $(p<5 E-8)$ with lower $\log \mathrm{WMH}$ volume (beta=-0.74, se=0.13) in 17,830 individuals. This variant is a predicted splice donor loss-of-function (LoF) variant in GBE1 (rs192044702, c.691+2T>C, MAF=0.00131) encoding 1,4-alpha-glucan branching enzyme 1. We further found three single variants in KLHL21 (rs891958177), PARP2 (rs750147320), and $A B C C 1$ ( $r$ 748043154) to reach a suggestive threshold of $\mathrm{p}<5 \mathrm{E}-7$ for association with logWMH volume (Supp Table 2).

\section{Whole-exome burden test reveals HTRA1 as a risk gene for WMH burden}

We next performed a whole-exome burden test using the Combined Multivariate and Collapsing (CMC) method implemented in the rvtests software.-Analyses were corrected for sex, age at imaging, and 10 genomic PCs as covariates with logWMH volume as the dependent variable ( $\mathrm{N}=16,511$ unrelated individuals). The results were subsequently filtered to retain genes with $>20$ alternative alleles in the analyzed dataset. HTRA1 was the only gene significantly associated at an FDR level of $5 \%$ ( $p=5.6 \mathrm{E}-6$ ), based on 59 alternative HTRA1 allele carriers (prevalence of $\sim 3.6 / 1000$ in the UKB) at 18 genomic positions. Four additional genes including $G B E 1, D C A K D$, EGFL8 and RGS12 showed suggestive association at an FDR level of 25\% (Table 1, Supp Table 3, Supp Fig 1). To estimate the effects of carrier status on logWMH volume we performed linear regression analysis on log transformed WMH volume and minor allele carrier status, corrected for sex, age at imaging, and 10 genomic PCs. Carriers of rare variants in either HTRA1, EGFL8 or RGS12 showed increased WMH volumes compared to non-carriers (HTRA1: beta $=0.36$, se $=0.09, p=0.0003$; EGFL8: beta $=0.22$, se=0.06, $p=9.6 \mathrm{E}-5 ;$ RGS12: beta $=0.29$, se $=0.10, p=0.003$, 
medRxiv preprint doi: https://doi.org/10.1101/2021.03.26.21253954; this version posted March 29, 2021. The copyright holder for this preprint

respectively), whereas carriers of rare variants in $G B E 1$ (beta $=-0.20$, se $=0.05$, $\mathrm{p}=6.7 \mathrm{E}-5$ ) and DCAKD (beta=-0.21, se=0.05, $\mathrm{p}=0.0002$ ) showed lower WMH volumes. The results did not materially change when further correcting for vascular risk factors (SBP, LDL, Hba1C, BMI and smoking) (Supp Table 4) In an additional sensitivity analysis, we only considered LoF mutations in the exome-wide burden test. The associations of GBE1, DCAKD and EGFL8 with WMH volume were of similar magnitude as in the combined missense and LoF analysis. (Supp Table 5) In contrast, the association of HTRA1, which was based on only 9 LoF variants, was greatly diminished $(\mathrm{p}=0.97)$, and therefore, HTRA1 LoF variants were not considered in further analyses. There was no association with LoF alleles in RGS12 ( $\mathrm{p}=0.69)$.

\section{Domain-specific burden test of HTRA1 shows specific association with the protease domain}

Given the association between rare variants in HTRA1 and WMH volume in the burden tests and the overall structure of the HTRA1 protease, which is organized into functionally distinct domains (Fig 1), we next repeated the analyses focusing on rare missense variants in individual domains. Specifically, we performed a separate CMC burden test for the signal peptide (AA 1-22, $N=2$ variants, prevalence 7.8/1000), IGFBP domain (AA 33-100, N=6 variants, prevalence 0.6/1000), Kazal-like domain (AA 100-157, N=4 variants, prevalence 0.9/1000), protease domain (AA 204-364, $\mathrm{N}=9$ variants, prevalence 2.2/1000) and PDZ domain (AA 365-467, $\mathrm{N}=11$ variants, prevalence 1.6/1000). Rare missense variants in the HTRA1 protease domain were significantly associated with altered WMH volumes $(p=9.5 E-8)$, whereas there was no signal for the other domains (Fig 1 and Table 2) and the results remained stable after exclusion of one compound heterozygote individual (D320N / R403W). Baseline characteristics of protease domain variant carriers did not differ from those of noncarriers (Supp Table 6). We also calculated results for the combined protease and linker domain as the linker domain (AA 158-204; 2 variants) serves as an activator of protease function and found the association to be slightly attenuated ( $p=5.5 E-7)$.

To approximate the effects of carrier status on WMH volume, we performed linear regression analysis correcting for sex, age at imaging, and 10 genomic PCs. Carrier status of an alternative allele in the HTRA1 protease domain was associated with an increase in logWMH volume (beta $=0.79$, se $=0.14, p=9.4 E-8$; FDR $<5 \%$ ) whereas we 
medRxiv preprint doi: https://doi.org/10.1101/2021.03.26.21253954; this version posted March 29, 2021. The copyright holder for this preprint (which was not certified by peer review) is the author/funder, who has granted medRxiv a license to display the preprint in perpetuity.

It is made available under a CC-BY-NC-ND 4.0 International license .

found no effect of carrier status on WMH volume in other domains (Table 2). In an age-stratified analysis, carriers exhibited logWMH volumes comparable to noncarriers that were 11.4 years older (Fig 1B). When compared to other dichotomized risk factors for $\mathrm{WMH}$ volume, protease domain mutation carrier status showed a larger effect than hypertension (beta=0.26, se=0.02), diabetes (beta=0.25, se=0.04), BMI (beta=0.18, se=0.01) and smoking (beta=0.10, se=0.01). Also, comparison to individuals on a polygenic risk score (PRS) distribution based on 27 common genetic variants (Sargurupremraj et al., 2020) showed a larger effect size for carrier status of an alternative allele in the HTRA1 protease domain than for individuals with a PRS above vs below the $99.8 \%$ percentile of the PRS distribution (beta=0.44, se=0.14) (Fig 2).

\section{Mutations in the HTRA1 protease domain are associated with a loss of protease activity}

To further elucidate the functional consequence of the identified HTRA1 variants, we performed activity assays using human cell-derived recombinant proteins (Fig 3). Specifically, we evaluated HTRA1 protease activity towards its known physiological substrate LTBP1. Wild type (wt) HTRA1 and an active site mutant (ASM) obtained by replacement of the catalytic Ser by an Ala (S328A) served as positive and negative controls, respectively. We investigated the enzymatic activity of 2 Kazal-like domain, 2 PDZ domain and 9 protease domain mutants. Three known CARASIL loss-offunction mutants were also included in the assays (Beaufort et al., 2014; Nozaki et al., 2016). We found the protease activity of Kazal-like and PDZ domain mutants to be comparable to that of wt HTRA1, in accord with the fact that these domains are dispensable for protease activity (Eigenbrot et al., 2012; Uemura et al., 2020). In contrast, 6 out of 9 protease domain mutants exhibited a marked reduction of protease activity (V221L, V221M, R227W, P275L, M314V, D320N).

\section{EGFL8 is proteolytically processed by HTRA1 and expressed in the human brain vasculature}

Given the prominence of variants in the HTRA1 protease domain in the association analyses and the result of the protease assays, we next performed a targeted 
medRxiv preprint doi: https://doi.org/10.1101/2021.03.26.21253954; this version posted March 29, 2021. The copyright holder for this preprint (which was not certified by peer review) is the author/funder, who has granted medRxiv a license to display the preprint in perpetuity.

It is made available under a CC-BY-NC-ND 4.0 International license .

analysis of genes encoding potential substrates of HTRA1. Potential substrates were identified from a recent proteomic study in Htra1 deficient mice (Zellner et al., 2018) that found 38 proteins to be enriched in the brain vasculature of $\mathrm{Htra} 1^{-/-}$compared to wild-type mice, among them several verified HTRA1 substrates including Efemp1, Vtn, and Ltbp1 (Lin et al., 2018; Zellner et al., 2018) (Supp Table 7). Notably, one of the most strongly enriched proteins in that dataset was Egfl8. Focusing on the corresponding genes encoding these 38 candidate substrates in our burden test, EGFL8 was the only gene that reached experiment-wide significance at an FDR level of $5 \%(p=1.54 E-4)$.

We next set out to experimentally determine whether the human EGFL8 protein is a substrate of HTRA1. Treatment of EGFL8 with HTRA1 resulted in a dose-dependent degradation of EGFL8, which was prevented in the presence of a selective HTRA1 inhibitor (Fig 4A). These observations thus identify EGFL8 as a novel HTRA1 substrate. We further examined the cerebral expression pattern of EGFL8 by immunohistochemistry. In the human cortex, EGFL8 was predominantly localized to the alpha smooth muscle actin positive vasculature, thus corresponding to arteries and arterioles (Fig 4B).

\section{Rare variants in the HTRA1 protease domain associate with multiple neurological and non-neurological phenotypes}

HTRA1 mutation carriers exhibit a wide range of cerebral and extracerebral phenotypes (Rannikmae et al., 2020). To comprehensively assess disease outcomes associated with rare variants in HTRA1 or EGFL8, we performed a rare-variant burden PheWAS on standardized Phecodes in the UK Biobank. Specifically, we matched patients' ICD10 codes (both primary, secondary and death-record based) to PheCodes. After excluding Phecodes that were sex-specific or had $<100$ cases in the analysis, 741 different Phecodes remained that were analyzed in burden tests. We further performed analyses for any stroke (AS), any ischemic stroke (AIS) and intracerebral hemorrhage $(\mathrm{ICH})$ as defined by the algorithmically defined stroke outcomes (UKB fields 42006-42013) and for parental history of stroke and family history of dementia (UKB field 20107 and 20110). 
Considering all identified damaging and LoF variants in HTRA1 (Supp Tables 8 and 9, we found conductive hearing loss (Phecode 389.2) to be associated at an FDR level of 5\% (Supp Table 10, Supp Fig 2) with minor allele carriers having a higher risk in Firth logistic regression (OR: 5.37, Cl95 [2.39-9.49]). Focusing on missense variants in the protease domain we identified 12 Phecodes at an FDR level of $5 \%$ (Fig 5, Table 3 and Supp Table 11) including migraine with aura (Phecode 340.1), encephalitis (Phecode 323), aneurysms and dissection of heart (Phecode 411.41), and heart valve replaced (Phecode 395.6). Notably, for all significant Phecodes minor allele carrier status was associated with higher risk of the respective phenotype. For EGFL8, we identified two Phecodes at an FDR level of 5\%: 578.8 (Hemorrhage of rectum and anus) and 696.41 (Psoriasis vulgaris), the latter confirming prior work in the UKB (Emdin et al., 2018) (Supp Table 12, Supp Fig 3). 
medRxiv preprint doi: https://doi.org/10.1101/2021.03.26.21253954; this version posted March 29, 2021. The copyright holder for this preprint (which was not certified by peer review) is the author/funder, who has granted medRxiv a license to display the preprint in perpetuity.

It is made available under a CC-BY-NC-ND 4.0 International license .

\section{DISCUSSION}

Using whole-exome sequencing data from the UK Biobank, we show that rare variants in HTRA1 are associated with a higher burden of radiological white matter hyperintensities in the general population. We further show that the association with WMH burden is largely restricted to variants affecting the HTRA1 protease domain and provide experimental evidence that variants giving the strongest association signal result in a loss of proteolytic activity of HTRA1. Our PheWAS results reveal that heterozygous variants in the HTRA1 protease domain, which are present at a frequency of 1 in 450 in the UKB population, are associated with a wide range of phenotypes including migraine with aura. We further demonstrate that the gene product of EGFL8, which shows suggestive association with $\mathrm{WMH}$ burden in the UKB, is a direct substrate of HTRA1 and is expressed in the brain vasculature. Collectively, these findings highlight an important role of the HTRA1 protease in maintaining white matter integrity and provide insights in disease mechanisms.

HTRA1 has been implicated in familial small vessel disease (SVD). Biallelic mutations in HTRA1 cause cerebral autosomal recessive arteriopathy with subcortical infarcts and leukoencephalopathy (CARASIL), an early-onset condition that is characterized by stroke, dementia, spondylosis deformans, and alopecia (Hara et al., 2009; Beaufort et al., 2014). In contrast, heterozygous mutations in HTRA1 cause an autosomal dominantly inherited SVD that displays a more restricted phenotype of stroke, cognitive decline, and gait disturbance and manifests at a later age of onset (Verdura et al., 2015). Our results extend these findings by showing that rare variants in HTRA1, and more specifically variants in the HTRA1 protease domain, are associated with WMH burden on a population-wide level. Notably, we found no association of such variants with stroke, dementia or a family history of stroke or dementia in the UKB. Instead, we found an association with both neurological and non-neurological phenotypes that have not previously been associated with HTRA1 mutations.

The domain-specific analyses for HTRA1 in combination with the protease assays suggest that the mechanism underlying the observed association between rare variants in HTRA1 and WMH burden is a loss of proteolytic function of the HTRA1 protease. This would be in line with the proposed mechanisms for mutations implicated in HTRA1-related familial SVD (Beaufort et al., 2014; Verdura et al., 2015). 
medRxiv preprint doi: https://doi.org/10.1101/2021.03.26.21253954; this version posted March 29, 2021. The copyright holder for this preprint (which was not certified by peer review) is the author/funder, who has granted medRxiv a license to display the preprint in perpetuity. It is made available under a CC-BY-NC-ND 4.0 International license .

However, our experiments focused on a set of variants identified in the UKB and were limited to biochemical assays using recombinant proteins. Other putative lossof-function mechanisms related to e.g., gene expression, mRNA or protein stability (Hara et al., 2009; Fasano et al., 2020) were not evaluated. Also, we did not go further in examining possible dominant negative effects, as recently reported for a subset of HTRA1 variants linked to hereditary SVD (Nozaki et al., 2016; Uemura et al., 2020). Of interest, one of the variants (D320N) detected here has previously been reported in an Asian CARASIL patient (Xie and Zhang, 2018) who was compound heterozygous for D320N. In contrast, R227W, which had an allele frequency of $0.04 \%$ in the UKB population with available WES data $(0.06 \%$ in those with imaging), was associated with $\mathrm{WMH}$ burden and has so far not been linked to neurological disease. More work is needed to delineate genotype-phenotype correlations at this locus.

While DCAKD and EGFL8 did not reach exome-wide significance for association with $\mathrm{WMH}$ burden, we consider these genes to exhibit strong evidence for a causal involvement in WMH: Recent GWAS found common variants at DCAKD to reach genome-wide significance for association with $\mathrm{WMH}$ while leaving the responsible gene unidentified (Persyn et al., 2020; Sargurupremraj et al., 2020). The current study pinpoints DCAKD as a likely causal gene in this region and further demonstrates a role of rare variants in DCAKD. A causal involvement of EGFL 8 is supported by the following observations. First, we found the gene product of EGFL8 to be efficiently cleaved by HTRA1 in our protease assays, thus demonstrating a functional interaction between EGFL8 and a protease with an established role in SVD and cerebral WMH. Notably, common variants in EFEMP1 encoding another substrate of HTRA1 (Lin et al., 2018; Armstrong et al., 2020; Persyn et al., 2020; Sargurupremraj et al., 2020), have consistently been associated with WMH in recent GWAS (Lin et al., 2018; Armstrong et al., 2020; Persyn et al., 2020; Sargurupremraj et al., 2020). Second, we found human EGFL8 to be prominently expressed in the brain vasculature, which would be in line with the role of vascular mechanisms in WMH. The biological function of EGFL8, encoding 'EGF Like Domain Multiple 8', remains largely unexplored. A recent study (Weiss et al., 2021) found EGFL8 to act as neuritogen and to rewire cellular signaling by activating kinases involved in neurogenesis. Notably, EGFL7, a close paralogue of EGFL8, which is likewise expressed in brain vessels, has been implicated in various vascular functions 
medRxiv preprint doi: https://doi.org/10.1101/2021.03.26.21253954; this version posted March 29, 2021. The copyright holder for this preprint (which was not certified by peer review) is the author/funder, who has granted medRxiv a license to display the preprint in perpetuity.

It is made available under a CC-BY-NC-ND 4.0 International license .

including angiogenesis and elastogenesis (Parker et al., 2004; Lelievre et al., 2008; Nichol and Stuhlmann, 2012). DCAKD, encoding 'Dephospho-CoA Kinase Domain Containing protein', is ubiquitously expressed in brain, has a putative role in neurodevelopment, and has previously been shown to be implicated in psychiatric disease (Bipolar Disorder Schizophrenia Working Group of the Psychiatric Genomics Consortium, 2018; Barbu et al., 2020). Moreover, studies on expression quantitative loci (eQTL) have linked expression levels of DCAKD to white matter microstructure and WMH volume (Barbu et al., 2020; Persyn et al., 2020).

Among the phenotypes shown here to be associated with rare variants in the HTRA1 protease domain is migraine with aura thus pointing to a potential mechanistic link between WMH and migraine with aura. Previous population-based studies found a higher frequency of radiological WMH in migraineurs (Kruit et al., 2004; Kurth et al., 2011; Palm-Meinders et al., 2012; Hamedani et al., 2013). However, this was not consistently observed in other studies (Monteith et al., 2014; Gaist et al., 2016) and there was no clear pattern in terms of a preferential association with migraine with aura compared to migraine without aura (Kruit et al., 2004; Kurth et al., 2011; PalmMeinders et al., 2012; Hamedani et al., 2013). Of further interest, common variant association studies reveal that several of the risk loci for migraine overlap with known risk loci for WMH including COL4A1, COL4A2, NBEAL1-CARF, and ADAMTSL4 (Persyn et al., 2020; Sargurupremraj et al., 2020; Hautakangas et al., 2021). The association between rare variants in HTRA1 and migraine with aura observed here further adds to recent GWAS that found common variants at HTRA1 to be associated with migraine (Gormley et al., 2016; Hautakangas et al., 2021). Studies in additional datasets are needed to better delineate the relationship between rare variants in HTRA1 and migraine and a potential mechanistic link with $\mathrm{WMH}$.

The setting of the UKB enabled us to provide an estimate of the frequency of rare variants and their impact on $\mathrm{WMH}$ on a population level. Altogether, we found rare variants in the HTRA1 protease domain to occur at a frequency of about 1 in 400 . As expected, some variants, such as R227W, were found to be more prevalent than others and effect sizes varied between variants although these results need to be interpreted with caution given the low number of risk allele carriers. Contrasting with the current gene-burden tests that considered rare variants in HTRA1, common variants at HTRA1 did not reach genome-wide significance for association with WMH in two recent GWAS that mostly included individuals from the general population 
medRxiv preprint doi: https://doi.org/10.1101/2021.03.26.21253954; this version posted March 29, 2021. The copyright holder for this preprint (which was not certified by peer review) is the author/funder, who has granted medRxiv a license to display the preprint in perpetuity.

It is made available under a CC-BY-NC-ND 4.0 International license .

(Persyn et al., 2020; Sargurupremraj et al., 2020). However, a recent candidate gene association study in population-based subjects with extreme $\mathrm{WMH}$ volumes found a common intronic variant in HTRA1 (rs2293871; allele frequency: 19\%) to be associated with WMH volume (Mishra et al., 2019). Also, HTRA1 reached genomewide significance in a multi-trait analysis that combined GWAS data on WMH and lacunar stroke (Traylor et al., 2021). Overall, these findings emphasize the relevance of HTRA1 for vascular brain injury beyond rare hereditary arteriopathies.

Our single variant analysis revealed one variant that reached exome-wide significance and three additional variants that reached suggestive evidence for association with WMH. rs192044702 in GBE1 has previously been reported in compound heterozygous individuals with glycogen storage disease IV (Fernandez et al., 2010; Ravenscroft et al., 2013), which is allelic to adult polyglucosan body disease (APBD, OMIM \#263570) (Mochel et al., 2012). The majority of patients with APBD have WMH on MRI (Mochel et al., 2012; Lopez Chiriboga, 2017), which seems at odds with our observation of a protective effect of rs192044702 on WMH burden. However, carriers of a single APBD mutation are generally asymptomatic and the effects by which variants in GBE1 might influence white matter integrity in one or the other direction remain poorly understood.

Our study has limitations. First, while the analysis of a quantitative trait offers higher statistical power than a binary phenotype our study still had limited power to detect small to moderate effect sizes. Also, the low number of alternative allele carriers may have resulted in inaccurate effect estimates with wide confidence intervals and potentially also false-positive findings. Second, as with any WES approach, there remains a possibility of errors in calling very rare variants. However, this would be expected to bias the results from gene burden tests towards the null hypothesis whereas we found a high consistency in the directionality of effects for associated variants in HTRA1. Also, despite rigorous QC of WES data in the UKB (Szustakowski et al., 2020), we cannot exclude the possibility of mis-called ultra-rare variants. Third, the results from our PheWAS might be more favorably powered for phenotypes with an early age-of onset. Given the relatively young age of UKB participants at study inclusion (mean age 56.8yrs) and the low number of participants with long-term follow up (median 8.98yrs) associations with late-onset phenotypes such as stroke and dementia might have been missed. As a possible indication we found rare variants in the HTRA1 protease domain to only reach nominal significance for Phecodes 
representing "transient cerebral ischemia" (Phecode 433.21) and "occlusion of cerebral arteries" (Phecode 433.31). Fourth, the level of phenotyping for stroke in the UKB precluded analyses restricted to lacunar stroke. Fifth, our PheWAS analysis was limited to hospital episode stay and death record ICD10 codes mapped to Phecodes. Several symptoms and phenotypes of interest (e.g. alopecia) are not sufficiently reflected by these codes. Sixth, we did not assess longitudinal changes in $\mathrm{WMH}$ burden as the number of individuals with available follow-up data on WMH in the UKB is still very low (approx. 1,500 individuals). Finally, our results cannot be extrapolated to other ethnicities and populations, which differ in terms of genetic architecture, vascular risk factors, and environmental factors (Brickman et al., 2008; 


\section{FUNDING}

This project received funding from the European Union's Horizon 2020 research and innovation programme (666881), SVDs@target (to MD; 667375), CoSTREAM (to MD); the DFG as part of the Munich Cluster for Systems Neurology (EXC 2145 SyNergy - ID 390857198), the CRC 1123 (B3; to MD) and DI 722/16-1 (project ID: 428668490); and the Fondation Leducq (Transatlantic Network of Excellence on the Pathogenesis of Small Vessel Disease of the Brain; to MD). ME is funded by Deutsche Forschungsgemeinschaft (EH 100/18-1). KR is funded by Health data Research UK Rutherford fellowship (MR/S004130/1). AF is funded by BHF award $\mathrm{RE} / 18 / 5 / 34216$.

\section{COMPETING INTERESTS}

The authors declare no competing interests. 
medRxiv preprint doi: https://doi.org/10.1101/2021.03.26.21253954; this version posted March 29, 2021. The copyright holder for this preprint (which was not certified by peer review) is the author/funder, who has granted medRxiv a license to display the preprint in perpetuity.

It is made available under a CC-BY-NC-ND 4.0 International license .

\section{TABLES}

Table 1. Whole-exome burden test on white matter hyperintensities

\begin{tabular}{|c|c|c|c|c|c|}
\hline Gene & $\begin{array}{c}\text { Genomic position } \\
\text { (hg38) }\end{array}$ & $\begin{array}{c}\text { No. of } \\
\text { rare } \\
\text { variants }\end{array}$ & $\begin{array}{c}\text { Minor allele } \\
\text { count }\end{array}$ & p-value & $\begin{array}{c}\text { FDR-adjusted } \\
\text { p-value }\end{array}$ \\
\hline HTRA1 & $10: 122461552-122514907$ & 18 & 59 & $\mathbf{5 . 5 E}-6$ & $\mathbf{0 . 0 4 4}$ \\
\hline GBE1 & $3: 81489704-81761645$ & 48 & 281 & $3.2 \mathrm{E}-5$ & 0.131 \\
\hline DCAKD & $17: 45023337-45061129$ & 9 & 225 & $7.1 \mathrm{E}-5$ & 0.192 \\
\hline EGFL8 & $6: 32164594-32168285$ & 15 & 237 & $1.5 \mathrm{E}-4$ & 0.229 \\
\hline RGS12 & $4: 3314146-3439913$ & 17 & 72 & $1.7 \mathrm{E}-4$ & 0.229 \\
\hline
\end{tabular}

Shown are genes reaching exome wide significance (FDR-adjusted $p<0.05$; in bold) or suggestive evidence (FDR-adjusted $p<0.25)$ for association with logWMH volume. The results are derived from a unidirectional mutivariable burden test (CMC) on logWMH and are adjusted for age at imaging, sex and the first 10 genomic principal components. Only variants that are predicted to be damaging (REVEL score $>0.5$ ) or predicted to exert a loss-of-function effect by LoFTEE were considered in the analysis. Genes with Minor allele count $<20$ were filtered out. 
Table 2. HTRA1 domain-specific burden test on white matter hyperintensities

\begin{tabular}{|c|c|c|c|c|c|}
\hline Domain & Variants & MAC & beta & se & p-value \\
\hline \multirow[t]{3}{*}{ Signal peptide } & & 129 & -0.02 & 0.07 & 7.80E-01 \\
\hline & P4S & 2 & -0.21 & 0.61 & 7.34E-01 \\
\hline & A20V & 127 & -0.07 & 0.08 & 3.79E-01 \\
\hline \multirow[t]{7}{*}{ IGFBP domain } & & 11 & 0.18 & 0.23 & 4.30E-01 \\
\hline & A35S & 1 & 0.66 & 0.87 & 4.45E-01 \\
\hline & G36V & 3 & -0.92 & 0.50 & 6.54E-02 \\
\hline & P50A & 2 & -0.52 & 0.61 & $4.01 \mathrm{E}-01$ \\
\hline & E51K & 1 & -1.53 & 0.87 & 7.77E-02 \\
\hline & G73D & 1 & -0.59 & 0.87 & 4.98E-01 \\
\hline & P82R & 3 & -0.42 & 0.50 & 4.06E-01 \\
\hline \multirow[t]{5}{*}{ Kazal domain } & & 15 & 0.12 & 0.22 & 5.20E-01 \\
\hline & R133G & 1 & 0.34 & 0.56 & 7.80E-01 \\
\hline & $\mathrm{R} 138 \mathrm{C}$ & 1 & 0.23 & 0.66 & $4.50 \mathrm{E}-01$ \\
\hline & Q151K & 12 & 0.02 & 0.25 & 9.34E-01 \\
\hline & Q157R & 1 & 0.32 & 0.87 & 7.17E-01 \\
\hline \multirow[t]{10}{*}{ Protease domain } & & 35 & 0.79 & 0.14 & 9.50E-08 \\
\hline & V221L & 1 & 1.87 & 0.87 & 3.10E-02 \\
\hline & V221M & 1 & 0.08 & 0.87 & $9.26 \mathrm{E}-01$ \\
\hline & R227W & 20 & 0.73 & 0.19 & 1.71E-04 \\
\hline & K248T & 1 & 0.85 & 0.87 & $3.26 \mathrm{E}-01$ \\
\hline & E272V & 3 & 0.03 & 0.50 & 9.59E-01 \\
\hline & P275L & 1 & 1.61 & 0.87 & 6.40E-02 \\
\hline & M314V & 1 & 0.48 & 0.87 & 5.83E-01 \\
\hline & D320N & 6 & 1.17 & 0.35 & 9.77E-04 \\
\hline & K362N & 1 & 1.82 & 0.87 & 3.60E-02 \\
\hline \multirow[t]{12}{*}{ PDZ domain } & & 26 & 0.06 & 0.17 & 4.30E-01 \\
\hline & A372V & 1 & 0.53 & 0.61 & 3.89E-01 \\
\hline & R403W & 3 & 1.01 & 0.50 & 4.51E-02 \\
\hline & V417I & 1 & 1.06 & 0.87 & 2.24E-01 \\
\hline & $\mathrm{D} 420 \mathrm{E}$ & 4 & 0.26 & 0.43 & 5.49E-01 \\
\hline & S436G & 1 & -0.54 & 0.87 & 5.35E-01 \\
\hline & V442M & 1 & -0.96 & 0.87 & $2.71 \mathrm{E}-01$ \\
\hline & A445T & 4 & 0.30 & 0.43 & 4.95E-01 \\
\hline & D450N & 2 & 0.01 & 0.61 & 9.83E-01 \\
\hline & V451I & 6 & -0.30 & 0.35 & 4.05E-01 \\
\hline & V461A & 1 & 0.36 & 0.87 & $6.75 \mathrm{E}-01$ \\
\hline & R463C & 2 & -0.02 & 0.61 & 9.72E-01 \\
\hline
\end{tabular}

The results are derived from a mutivariable burden test (CMC, for domains) or from a Wald association statistic (for single variants). All analyses were adjusted for age at imaging, sex and the first 10 genomic principal components. All missense variants mapping to the respective domains were considered. Results are displayed for the specific domains (grey) or the single variants. 
Table 3. HTRA1 protease domain PheWAS

\begin{tabular}{|c|c|c|c|c|c|}
\hline Phecode & Phenotype & P-value & $\begin{array}{c}\text { FDR- } \\
\text { Adjusted } \\
\text { P-value }\end{array}$ & $\begin{array}{l}\text { Odds } \\
\text { Ratio }\end{array}$ & $\begin{array}{c}95 \% \\
\text { Confidence } \\
\text { Interval }\end{array}$ \\
\hline 389.2 & Conductive hearing loss & $3.60 \mathrm{E}-06$ & 0.0025 & 10.75 & $2.99-26.90$ \\
\hline 571.6 & Primary biliary cirrhosis & 3.37E-05 & 0.012 & 13.37 & $2.77-38.77$ \\
\hline 411.41 & Aneurysm and dissection of heart & $6.34 \mathrm{E}-05$ & 0.015 & 6.68 & $2.22-15.20$ \\
\hline 340.1 & Migraine with aura & 8.31E-05 & 0.015 & 12.24 & $2.54-35.25$ \\
\hline 395.6 & Heart valve replaced & 0.00011 & 0.016 & 4.70 & $1.92-9.49$ \\
\hline 323 & Encephalitis & 0.00016 & 0.019 & 11.43 & $2.38-32.92$ \\
\hline 291.8 & Alteration of consciousness & 0.00018 & 0.019 & 7.68 & 2.14-19.13 \\
\hline 324 & Other CNS infection and poliomyelitis & 0.00027 & 0.024 & 10.80 & $2.24-31.13$ \\
\hline 575.1 & Cholangitis & 0.00042 & 0.032 & 7.08 & $1.97-17.68$ \\
\hline 613.1 & Inflammatory disease of breast & 0.00044 & 0.032 & 7.04 & $1.96-17.64$ \\
\hline 857 & Mechanical complication of unspecified genitourinary device, implant, graft & 0.00055 & 0.036 & 4.62 & $1.74-9.78$ \\
\hline 465 & Acute upper respiratory infections of multiple or unspecified sites & 0.00067 & 0.040 & 4.53 & $1.70-9.58$ \\
\hline
\end{tabular}

Results from a PheWAS analysis using Phecodes as the phenotypes of interest. Shown is the association of variants in the protease domain of HTRA1 with the individual Phecodes in a CMC burden test. Odds Ratios were calculated using Firth's regression and rare allele carrier status as an independent variable. FDR: false discovery rate. 


\section{FIGURE LEGENDS}

Figure 1. Overview of rare HTRA1 variants and the association with WMH burden. (A) shown is the domain structure of the HTRA1 protein and the position of rare missense variants in the 16,511 UK Biobank participants included in the current analysis. Vertical lines reflect effect sizes (line length) and directionality of effect (increasing vs. decreasing) of the respective variant on $\mathrm{WMH}$ volume. Variants reaching statistical significance in single variant tests $(\mathrm{p}<0.05)$ are shown in bold with the number of minor allele carriers indicated below.

(B) violin plot of age-stratified $\mathrm{WMH}$ burden in the UK Biobank. Carriers of a rare variant in the HTRA1 protease domain are depicted in red. The dashed lines represent fitted linear regression lines (WMH age) for all participants (black) and protease mutations carriers (red).

(C) example brain MRI images of HTRA1 protease domain variant carriers and agematched non-carriers.

Figure 2. Effect size of protease domain variant carrier status on logWMH volume in comparison with established risk factors.

Shown are the effect sizes and standard errors of dichotomized risk factors (age, hypertension, diabetes, smoking, BMI), a dichotomized polygenic risk score based on common genetic variants, and HTRA1 protease domain variant carrier status. Effect sizes and standard errors were derived for logWMH volume change using a linear regression model adjusting for age, sex and 10 genetic PCs.

Figure 3. Functional consequences of rare HTRA1 variants.

(A) Culture medium from transfected cells was collected to assess HTRA1 expression (anti-Myc immunoblot) and protease activity towards LTBP1 (anti-V5 immunoblots). ASM: active site mutant.

(B) Protease activity was determined as the ratio between cleaved (grey arrowhead) and intact (black arrowhead) LTBP1 and was normalized to HTRA1 levels. Data are presented as box-and-whisker plots (median +- standard error of mean; the activity of 
medRxiv preprint doi: https://doi.org/10.1101/2021.03.26.21253954; this version posted March 29, 2021. The copyright holder for this preprint (which was not certified by peer review) is the author/funder, who has granted medRxiv a license to display the preprint in perpetuity.

It is made available under a CC-BY-NC-ND 4.0 International license .

wt HTRA1 was set to 1). Data points represent independent measurements. At least three independent biological replicates were analyzed. ASM: active site mutant.

Figure 4. EGFL8 is a direct substrate of HTRA1 and expressed in the human brain vasculature.

(A) EGFL8 was exposed to increasing concentrations of purified HTRA1 in the absence or presence of an HTRA1 inhibitor. EGFL8 and HTRA1 were detected by anti-Myc and anti-HTRA1 immunoblots, respectively.

(B) Immunohistochemical detection of EGFL8 in human brain sections. The vascular basement membrane component collagen IV (Coll. IV) and the smooth muscle cell marker alpha smooth muscle actin (SMA) were detected as controls. Shown are representative images. Scale bar: $50 \mu \mathrm{m}$.

Figure 5. Rare variants in the HTRA1 protease domain associate with multiple neurological and non-neurological phenotypes.

Phenome-wide association study (PheWAS) Manhattan plot for carriers of rare variants in the HTRA1 protease domain. Shown are all standardized Phecodes along with stroke-related phenotypes. For phenotypes to the right, HTRA1 protease domain variant carriers show higher risk, for phenotypes to the left, carriers are at lower risk. The red dashed line represents the FDR 5\% cut-off. 


\section{REFERENCES}

Alfaro-Almagro F, Jenkinson M, Bangerter NK, Andersson JLR, Griffanti L, Douaud G, et al. Image processing and Quality Control for the first 10,000 brain imaging datasets from UK Biobank. Neuroimage 2018; 166: 400-24.

Armstrong NJ, Mather KA, Sargurupremraj M, Knol MJ, Malik R, Satizabal CL, et al. Common Genetic Variation Indicates Separate Causes for Periventricular and Deep White Matter Hyperintensities. Stroke 2020; 51(7): 2111-21.

Barbu MC, Spiliopoulou A, Colombo M, McKeigue P, Clarke TK, Howard DM, et al. Expression quantitative trait loci-derived scores and white matter microstructure in UK Biobank: a novel approach to integrating genetics and neuroimaging. TransI Psychiatry 2020; 10(1): 55.

Beaufort N, Scharrer E, Kremmer E, Lux V, Ehrmann M, Huber R, et al. Cerebral small vessel disease-related protease HtrA1 processes latent TGF-beta binding protein 1 and facilitates TGF-beta signaling. Proc Natl Acad Sci U S A 2014; 111(46): 16496-501.

Bipolar Disorder Schizophrenia Working Group of the Psychiatric Genomics Consortium. Genomic Dissection of Bipolar Disorder and Schizophrenia, Including 28 Subphenotypes. Cell 2018; 173(7): 1705-15 e16.

Brickman AM, Schupf N, Manly JJ, Luchsinger JA, Andrews H, Tang MX, et al. Brain morphology in older African Americans, Caribbean Hispanics, and whites from northern Manhattan. Arch Neurol 2008; 65(8): 1053-61.

Bycroft C, Freeman C, Petkova D, Band G, Elliott LT, Sharp K, et al. The UK Biobank resource with deep phenotyping and genomic data. Nature 2018; 562(7726): 203-9.

Cho BPH, Nannoni S, Harshfield EL, Tozer D, Graf S, Bell S, et al. NOTCH3 variants are more common than expected in the general population and associated with stroke and vascular dementia: an analysis of 200000 participants. J Neurol Neurosurg Psychiatry 2021.

Debette S, Markus HS. The clinical importance of white matter hyperintensities on brain magnetic resonance imaging: systematic review and meta-analysis. BMJ 2010; 341: c3666.

Debette S, Schilling S, Duperron MG, Larsson SC, Markus HS. Clinical Significance of Magnetic Resonance Imaging Markers of Vascular Brain Injury: A Systematic Review and Meta-analysis. JAMA Neurol 2019; 76(1): 81-94.

Dichgans M, Leys D. Vascular Cognitive Impairment. Circ Res 2017; 120(3): 573-91.

Dichgans M, Mayer M, Uttner I, Bruning R, Muller-Hocker J, Rungger G, et al. The phenotypic spectrum of CADASIL: clinical findings in 102 cases. Ann Neurol 1998; 44(5): 731-9.

Dichgans M, Pulit SL, Rosand J. Stroke genetics: discovery, biology, and clinical applications. Lancet Neurol 2019; 18(6): 587-99.

Dufouil C, de Kersaint-Gilly A, Besancon V, Levy C, Auffray E, Brunnereau L, et al. Longitudinal study of blood pressure and white matter hyperintensities: the EVA MRI Cohort. Neurology 2001; 56(7): 9216.

Duperron MG, Tzourio C, Sargurupremraj M, Mazoyer B, Soumare A, Schilling S, et al. Burden of Dilated Perivascular Spaces, an Emerging Marker of Cerebral Small Vessel Disease, Is Highly Heritable. Stroke 2018; 49(2): 282-7.

Eigenbrot C, Ultsch M, Lipari MT, Moran P, Lin SJ, Ganesan R, et al. Structural and functional analysis of HtrA1 and its subdomains. Structure 2012; 20(6): 1040-50. 
Emdin CA, Khera AV, Chaffin M, Klarin D, Natarajan P, Aragam K, et al. Analysis of predicted loss-offunction variants in UK Biobank identifies variants protective for disease. Nat Commun 2018; 9(1): 1613.

Fasano A, Formichi P, Taglia I, Bianchi S, Di Donato I, Battisti C, et al. HTRA1 expression profile and activity on TGF-beta signaling in HTRA1 mutation carriers. J Cell Physiol 2020; 235(10): 7120-7.

Fernandez C, Halbert C, De Paula AM, Lacroze V, Froissart R, Figarella-Branger D, et al. Non-lethal neonatal neuromuscular variant of glycogenosis type IV with novel GBE1 mutations. Muscle Nerve 2010; 41(2): 269-71.

Flannick J, Mercader JM, Fuchsberger C, Udler MS, Mahajan A, Wessel J, et al. Exome sequencing of 20,791 cases of type 2 diabetes and 24,440 controls. Nature 2019; 570(7759): 71-6.

Fornage M, Debette S, Bis JC, Schmidt H, Ikram MA, Dufouil C, et al. Genome-wide association studies of cerebral white matter lesion burden: the CHARGE consortium. Ann Neurol 2011; 69(6): 92839.

Gaist D, Garde E, Blaabjerg M, Nielsen HH, Kroigard T, Ostergaard K, et al. Migraine with aura and risk of silent brain infarcts and white matter hyperintensities: an MRI study. Brain 2016; 139(Pt 7): 2015-23.

Garde E, Mortensen EL, Krabbe K, Rostrup E, Larsson HB. Relation between age-related decline in intelligence and cerebral white-matter hyperintensities in healthy octogenarians: a longitudinal study. Lancet 2000; 356(9230): 628-34.

Georgakis MK, Duering M, Wardlaw JM, Dichgans M. WMH and long-term outcomes in ischemic stroke: A systematic review and meta-analysis. Neurology 2019; 92(12): e1298-e308.

Gormley P, Anttila V, Winsvold BS, Palta P, Esko T, Pers TH, et al. Meta-analysis of 375,000 individuals identifies 38 susceptibility loci for migraine. Nat Genet 2016; 48(8): 856-66.

Gould DB, Phalan FC, van Mil SE, Sundberg JP, Vahedi K, Massin P, et al. Role of COL4A1 in smallvessel disease and hemorrhagic stroke. N Engl J Med 2006; 354(14): 1489-96.

Grau S, Baldi A, Bussani R, Tian X, Stefanescu R, Przybylski M, et al. Implications of the serine protease HtrA1 in amyloid precursor protein processing. Proc Natl Acad Sci U S A 2005; 102(17): 6021-6.

Griffanti L, Zamboni G, Khan A, Li L, Bonifacio G, Sundaresan V, et al. BIANCA (Brain Intensity AbNormality Classification Algorithm): A new tool for automated segmentation of white matter hyperintensities. Neuroimage 2016; 141: 191-205.

Hamedani AG, Rose KM, Peterlin BL, Mosley TH, Coker LH, Jack CR, et al. Migraine and white matter hyperintensities: the ARIC MRI study. Neurology 2013; 81(15): 1308-13.

Hara K, Shiga A, Fukutake T, Nozaki H, Miyashita A, Yokoseki A, et al. Association of HTRA1 mutations and familial ischemic cerebral small-vessel disease. N Engl J Med 2009; 360(17): 1729-39.

Hautakangas H, Winsvold BS, Ruotsalainen SE, Bjornsdottir G, Harder AVE, Kogelman LJA, et al. Genome-wide analysis of 102,084 migraine cases identifies 123 risk loci and subtype-specific risk alleles. medRxiv 2021: 2021.01.20.21249647.

loannidis NM, Rothstein JH, Pejaver V, Middha S, McDonnell SK, Baheti S, et al. REVEL: An Ensemble Method for Predicting the Pathogenicity of Rare Missense Variants. Am J Hum Genet 2016; 99(4): 877-85.

Jeanne M, Gould DB. Genotype-phenotype correlations in pathology caused by collagen type IV alpha 1 and 2 mutations. Matrix Biol 2017; 57-58: 29-44.

Jian X, Satizabal CL, Smith AV, Wittfeld K, Bis JC, Smith JA, et al. Exome Chip Analysis Identifies Low-Frequency and Rare Variants in MRPL38 for White Matter Hyperintensities on Brain Magnetic Resonance Imaging. Stroke 2018; 49(8): 1812-9. 
medRxiv preprint doi: https://doi.org/10.1101/2021.03.26.21253954; this version posted March 29, 2021. The copyright holder for this preprint (which was not certified by peer review) is the author/funder, who has granted medRxiv a license to display the preprint in perpetuity.

It is made available under a CC-BY-NC-ND 4.0 International license .

Joutel A, Corpechot C, Ducros A, Vahedi K, Chabriat $\mathrm{H}$, Mouton $\mathrm{P}$, et al. Notch3 mutations in CADASIL, a hereditary adult-onset condition causing stroke and dementia. Nature 1996; 383(6602): 707-10.

Jurgens SJ, Choi SH, Morrill VN, Chaffin M, Pirruccello JP, Halford JL, et al. Rare Genetic Variation Underlying Human Diseases and Traits: Results from 200,000 Individuals in the UK Biobank. bioRxiv 2020: 2020.11.29.402495.

Karczewski KJ, Francioli LC, Tiao G, Cummings BB, Alfoldi J, Wang Q, et al. The mutational constraint spectrum quantified from variation in 141,456 humans. Nature 2020; 581(7809): 434-43.

Kruit MC, van Buchem MA, Hofman PA, Bakkers JT, Terwindt GM, Ferrari MD, et al. Migraine as a risk factor for subclinical brain lesions. JAMA 2004; 291(4): 427-34.

Kurth T, Mohamed S, Maillard P, Zhu YC, Chabriat H, Mazoyer B, et al. Headache, migraine, and structural brain lesions and function: population based Epidemiology of Vascular Ageing-MRI study. BMJ 2011; 342: c7357.

Ladis Study Group. 2001-2011: a decade of the LADIS (Leukoaraiosis And DISability) Study: what have we learned about white matter changes and small-vessel disease? Cerebrovasc Dis $2011 ; 32(6)$ : $577-88$.

Lee S, Abecasis GR, Boehnke M, Lin X. Rare-variant association analysis: study designs and statistical tests. Am J Hum Genet 2014; 95(1): 5-23.

Lelievre E, Hinek A, Lupu F, Buquet C, Soncin F, Mattot V. VE-statin/egfl7 regulates vascular elastogenesis by interacting with lysyl oxidases. EMBO J 2008; 27(12): 1658-70.

Lin MK, Yang J, Hsu CW, Gore A, Bassuk AG, Brown LM, et al. HTRA1, an age-related macular degeneration protease, processes extracellular matrix proteins EFEMP1 and TSP1. Aging Cell 2018; 17(4): e12710.

Littlejohns TJ, Holliday J, Gibson LM, Garratt S, Oesingmann N, Alfaro-Almagro F, et al. The UK Biobank imaging enhancement of 100,000 participants: rationale, data collection, management and future directions. Nat Commun 2020; 11(1): 2624.

Lopez Chiriboga AS. Teaching Neurolmages: Prominent spinal cord atrophy and white matter changes in adult polyglucosan body disease. Neurology 2017; 88(20): e194-e5.

Malik R, Chauhan G, Traylor M, Sargurupremraj M, Okada Y, Mishra A, et al. Multiancestry genomewide association study of 520,000 subjects identifies 32 loci associated with stroke and stroke subtypes. Nat Genet 2018; 50(4): 524-37.

Manichaikul A, Mychaleckyj JC, Rich SS, Daly K, Sale M, Chen WM. Robust relationship inference in genome-wide association studies. Bioinformatics 2010; 26(22): 2867-73.

Mbatchou J, Barnard L, Backman J, Marcketta A, Kosmicki JA, Ziyatdinov A, et al. Computationally efficient whole genome regression for quantitative and binary traits. bioRxiv 2020: 2020.06.19.162354.

McLaren W, Gil L, Hunt SE, Riat HS, Ritchie GR, Thormann A, et al. The Ensembl Variant Effect Predictor. Genome Biol 2016; 17(1): 122.

Miller KL, Alfaro-Almagro F, Bangerter NK, Thomas DL, Yacoub E, Xu J, et al. Multimodal population brain imaging in the UK Biobank prospective epidemiological study. Nat Neurosci 2016; 19(11): 152336 .

Mishra A, Chauhan G, Violleau MH, Vojinovic D, Jian X, Bis JC, et al. Association of variants in HTRA1 and NOTCH3 with MRI-defined extremes of cerebral small vessel disease in older subjects. Brain 2019; 142(4): 1009-23. 
medRxiv preprint doi: https://doi.org/10.1101/2021.03.26.21253954; this version posted March 29, 2021. The copyright holder for this preprint (which was not certified by peer review) is the author/funder, who has granted medRxiv a license to display the preprint in perpetuity. It is made available under a CC-BY-NC-ND 4.0 International license .

Mochel F, Schiffmann R, Steenweg ME, Akman HO, Wallace M, Sedel F, et al. Adult polyglucosan body disease: Natural History and Key Magnetic Resonance Imaging Findings. Ann Neurol 2012; 72(3): 433-41.

Monteith T, Gardener H, Rundek T, Dong C, Yoshita M, Elkind MS, et al. Migraine, white matter hyperintensities, and subclinical brain infarction in a diverse community: the northern Manhattan study. Stroke 2014; 45(6): 1830-2.

Neurology Working Group of the Cohorts for Heart Aging Research in Genomic Epidemiology Consortium, the Stroke Genetics Network, the International Stroke Genetics Consortium. Identification of additional risk loci for stroke and small vessel disease: a meta-analysis of genome-wide association studies. Lancet Neurol 2016; 15(7): 695-707.

Nichol D, Stuhlmann H. EGFL7: a unique angiogenic signaling factor in vascular development and disease. Blood 2012; 119(6): 1345-52.

Nozaki H, Kato T, Nihonmatsu M, Saito Y, Mizuta I, Noda T, et al. Distinct molecular mechanisms of HTRA1 mutants in manifesting heterozygotes with CARASIL. Neurology 2016; 86(21): 1964-74.

Palm-Meinders IH, Koppen H, Terwindt GM, Launer LJ, Konishi J, Moonen JM, et al. Structural brain changes in migraine. JAMA 2012; 308(18): 1889-97.

Parker LH, Schmidt M, Jin SW, Gray AM, Beis D, Pham T, et al. The endothelial-cell-derived secreted factor Egfl7 regulates vascular tube formation. Nature 2004; 428(6984): 754-8.

Persyn E, Hanscombe KB, Howson JMM, Lewis CM, Traylor M, Markus HS. Genome-wide association study of MRI markers of cerebral small vessel disease in 42,310 participants. Nat Commun 2020; 11(1): 2175.

Poepsel S, Sprengel A, Sacca B, Kaschani F, Kaiser M, Gatsogiannis C, et al. Determinants of amyloid fibril degradation by the PDZ protease HTRA1. Nat Chem Biol 2015; 11(11): 862-9.

Rannikmae K, Henshall DE, Thrippleton S, Ginj Kong Q, Chong M, Grami N, et al. Beyond the Brain: Systematic Review of Extracerebral Phenotypes Associated With Monogenic Cerebral Small Vessel Disease. Stroke 2020; 51(10): 3007-17.

Ravenscroft G, Thompson EM, Todd EJ, Yau KS, Kresoje N, Sivadorai P, et al. Whole exome sequencing in foetal akinesia expands the genotype-phenotype spectrum of GBE1 glycogen storage disease mutations. Neuromuscul Disord 2013; 23(2): 165-9.

Rutten JW, Hack RJ, Duering M, Gravesteijn G, Dauwerse JG, Overzier M, et al. Broad phenotype of cysteine-altering NOTCH3 variants in UK Biobank: CADASIL to nonpenetrance. Neurology 2020; 95(13): e1835-e43.

Sargurupremraj M, Suzuki H, Jian X, Sarnowski C, Evans TE, Bis JC, et al. Cerebral small vessel disease genomics and its implications across the lifespan. Nat Commun 2020; 11(1): 6285.

Staples J, Qiao D, Cho MH, Silverman EK, University of Washington Center for Mendelian Genomics, Nickerson DA, et al. PRIMUS: rapid reconstruction of pedigrees from genome-wide estimates of identity by descent. Am J Hum Genet 2014; 95(5): 553-64.

Szustakowski JD, Balasubramanian S, Sasson A, Khalid S, Bronson PG, Kvikstad E, et al. Advancing Human Genetics Research and Drug Discovery through Exome Sequencing of the UK Biobank. medRxiv 2020: 2020.11.02.20222232.

Traylor M, Persyn E, Tomppo L, Klasson S, Abedi V, Bakker MK, et al. Genetic basis of lacunar stroke: a pooled analysis of individual patient data and genome-wide association studies. The Lancet Neurology 2021.

Uemura M, Nozaki H, Kato T, Koyama A, Sakai N, Ando S, et al. HTRA1-Related Cerebral Small Vessel Disease: A Review of the Literature. Front Neurol 2020; 11: 545. 
medRxiv preprint doi: https://doi.org/10.1101/2021.03.26.21253954; this version posted March 29, 2021. The copyright holder for this preprint (which was not certified by peer review) is the author/funder, who has granted medRxiv a license to display the preprint in perpetuity.

It is made available under a CC-BY-NC-ND 4.0 International license .

UniProt Consortium. UniProt: a worldwide hub of protein knowledge. Nucleic Acids Res 2019; 47(D1): D506-D15.

Verdura E, Herve D, Bergametti F, Jacquet C, Morvan T, Prieto-Morin C, et al. Disruption of a miR-29 binding site leading to COL4A1 upregulation causes pontine autosomal dominant microangiopathy with leukoencephalopathy. Ann Neurol 2016; 80(5): 741-53.

Verdura E, Herve D, Scharrer E, Amador Mdel M, Guyant-Marechal L, Philippi A, et al. Heterozygous HTRA1 mutations are associated with autosomal dominant cerebral small vessel disease. Brain 2015; 138(Pt 8): 2347-58.

Wang Q, Dhindsa RS, Carss K, Harper A, Nag A, Tachmazidou I, et al. Surveying the contribution of rare variants to the genetic architecture of human disease through exome sequencing of $177,882 \mathrm{UK}$ Biobank participants. bioRxiv 2020: 2020.12.13.422582.

Wardlaw JM, Smith C, Dichgans M. Mechanisms of sporadic cerebral small vessel disease: insights from neuroimaging. Lancet Neurol 2013; 12(5): 483-97.

Wardlaw JM, Smith C, Dichgans M. Small vessel disease: mechanisms and clinical implications. Lancet Neurol 2019; 18(7): 684-96.

Weiss T, Taschner-Mandl S, Janker L, Bileck A, Rifatbegovic F, Kromp F, et al. Schwann cell plasticity regulates neuroblastic tumor cell differentiation via epidermal growth factor-like protein 8 . Nat Commun 2021; 12(1): 1624.

Wu P, Gifford A, Meng X, Li X, Campbell H, Varley T, et al. Mapping ICD-10 and ICD-10-CM Codes to Phecodes: Workflow Development and Initial Evaluation. JMIR Med Inform 2019; 7(4): e14325.

Xie F, Zhang LS. A Chinese CARASIL Patient Caused by Novel Compound Heterozygous Mutations in HTRA1. J Stroke Cerebrovasc Dis 2018; 27(10): 2840-2.

Zahodne LB, Manly JJ, Narkhede A, Griffith EY, DeCarli C, Schupf NS, et al. Structural MRI Predictors of Late-Life Cognition Differ Across African Americans, Hispanics, and Whites. Curr Alzheimer Res 2015; 12(7): 632-9.

Zellner A, Scharrer E, Arzberger T, Oka C, Domenga-Denier V, Joutel A, et al. CADASIL brain vessels show a HTRA1 loss-of-function profile. Acta Neuropathol 2018; 136(1): 111-25.

Zhan X, Hu Y, Li B, Abecasis GR, Liu DJ. RVTESTS: an efficient and comprehensive tool for rare variant association analysis using sequence data. Bioinformatics 2016; 32(9): 1423-6. 


\section{Figure 1}

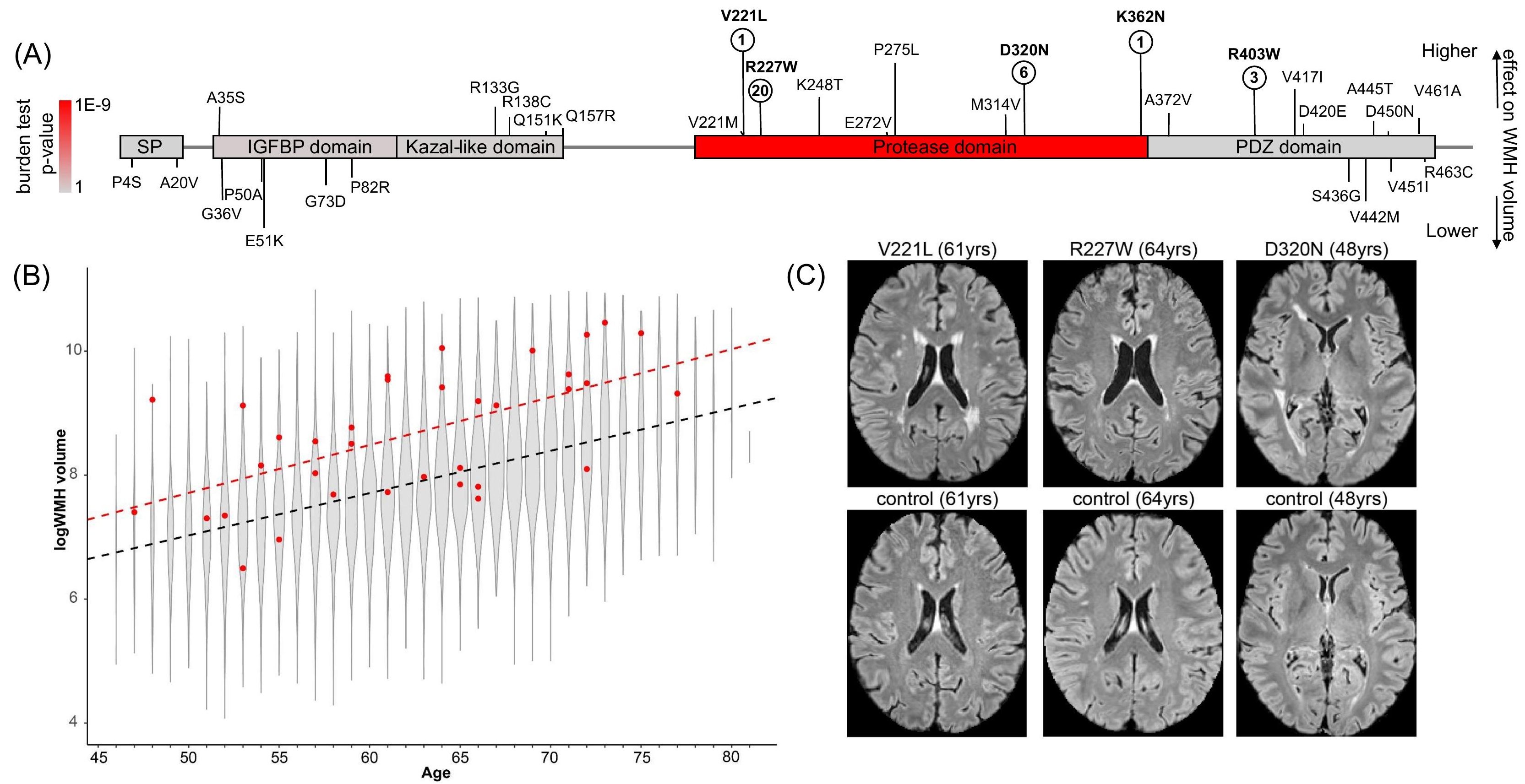


effect estimate se

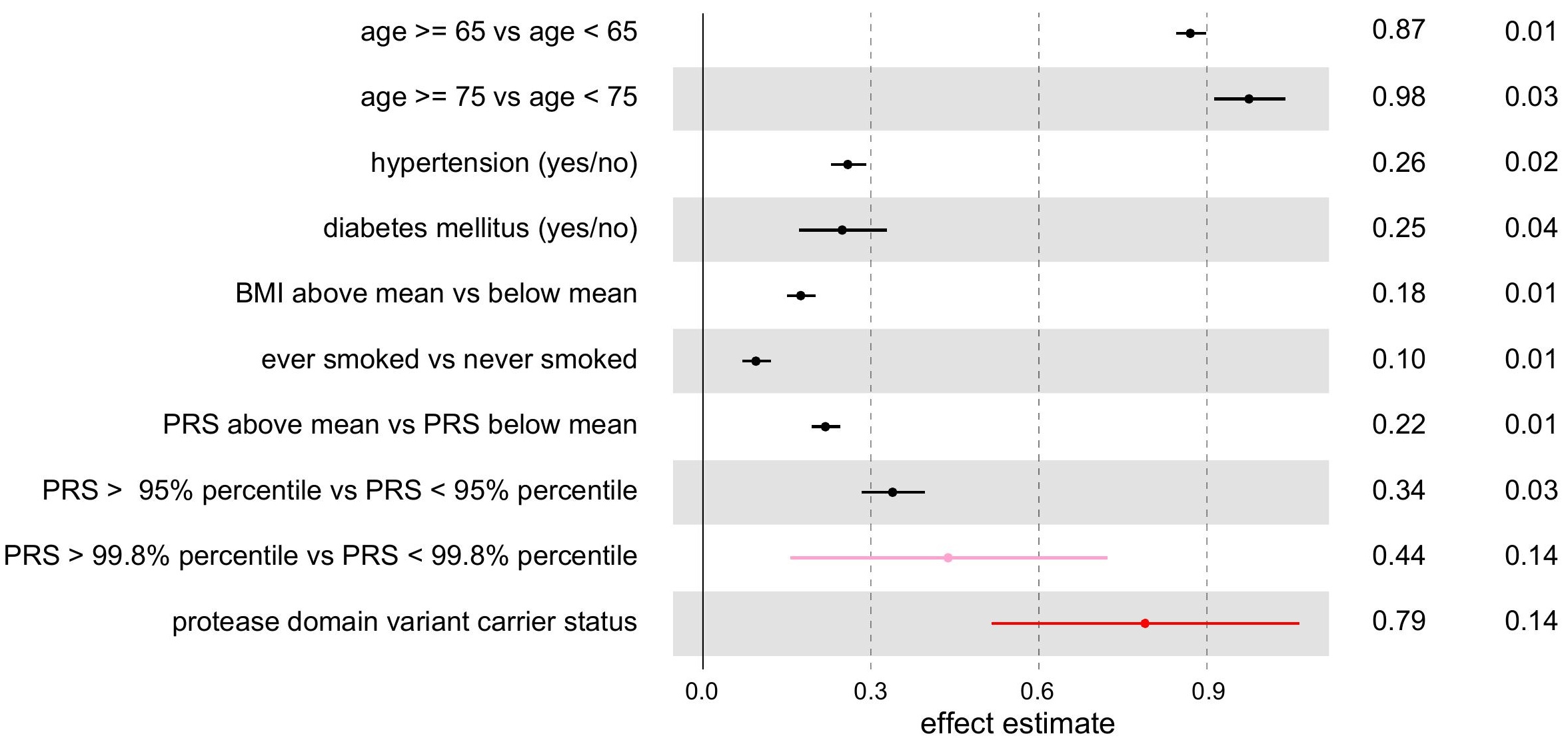




\section{Figure 3}

(A)
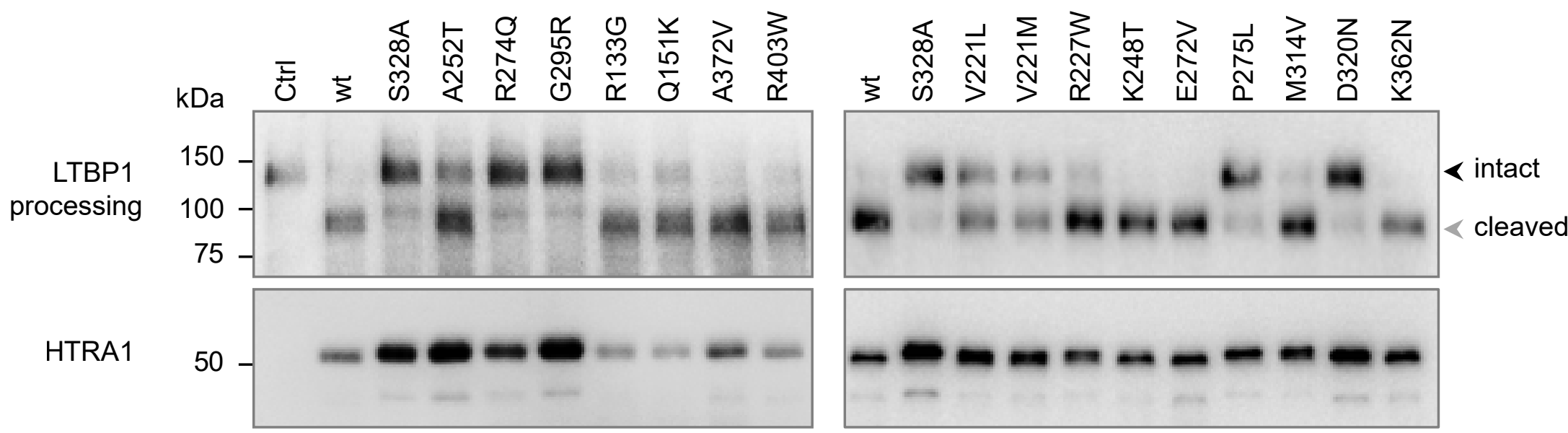

(B)

ASM CARASIL

Kazal-like/PDZ

protease domain mutations

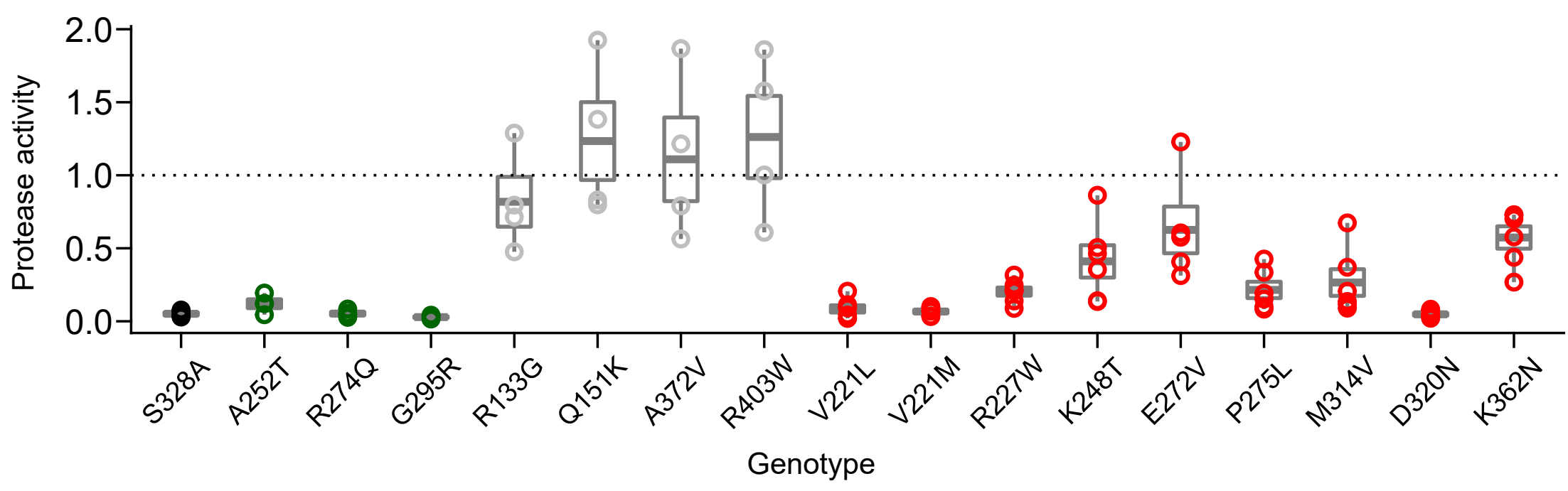




\section{Figure 4}

(A)

EGFL8 - + + + +

$\begin{array}{llllll}\mathrm{HTRA} 1(\mu \mathrm{M}) & .5 & 0 & .1 & .5 & .5\end{array}$

Inhibitor

$\mathrm{kDa}$

EGFL8

degradation

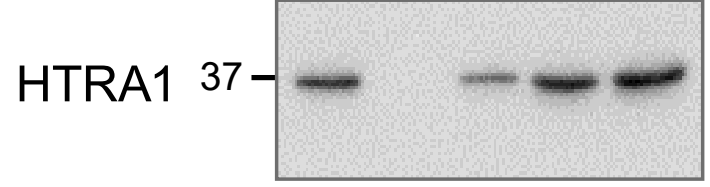

(B)

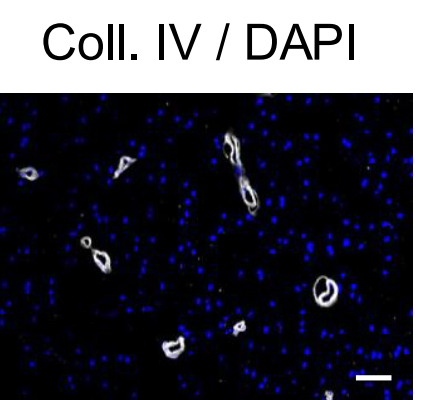

SMA

EGFL8
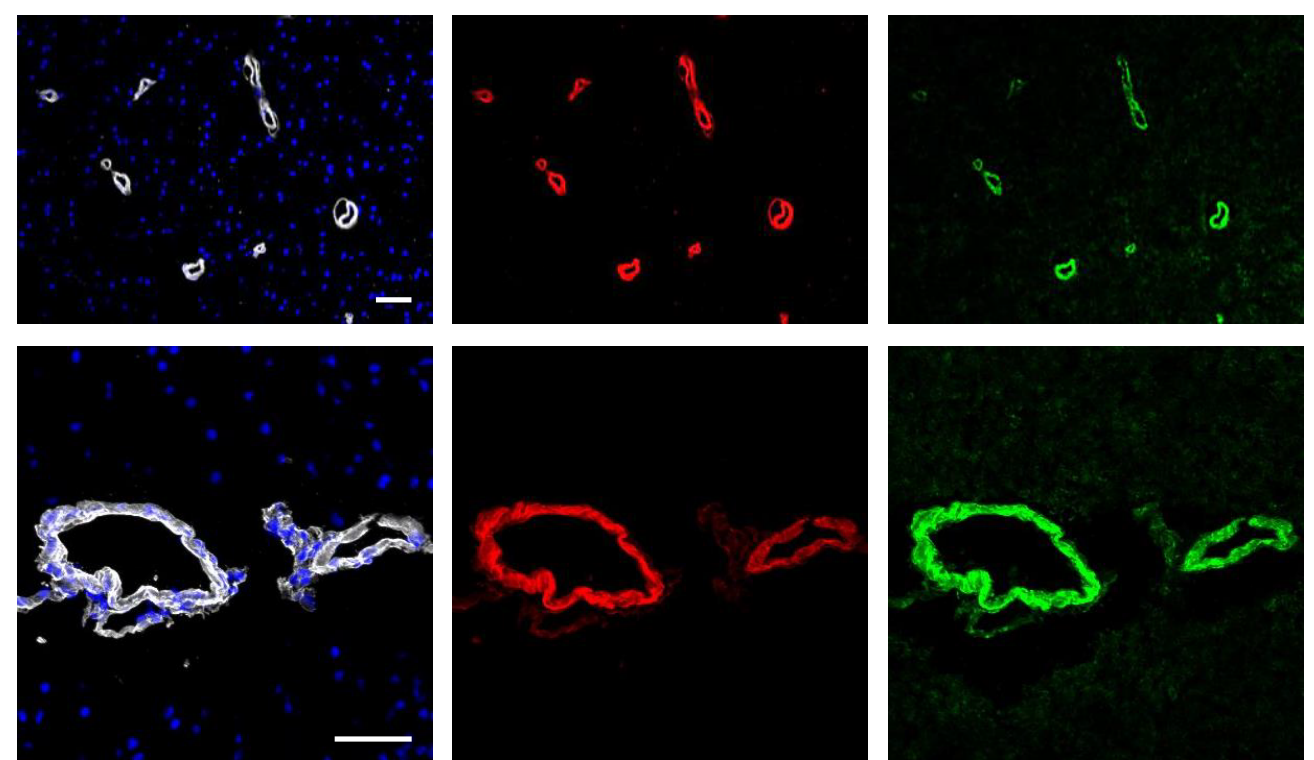
Hematopoietic

Mental disorders

Neurological

Sense organs

Circulatory system
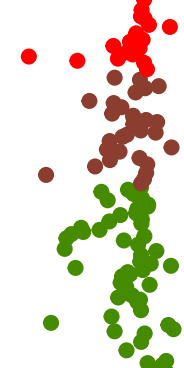

\section{Musculoskeletal}

Congenital anomalies

Symptoms

Injuries \& poisonings

Stroke

$$
-\log _{10}(p)
$$

Alteration of consciousness

Encephalitis

Migraine with aura

Conductive hearing loss

Heart valve replaced

Aneurysm and dissection of heart

Acute upper respiratory infections

Primary biliary cirrhosis

Cholangitis

-

Inflammatory disease of breast

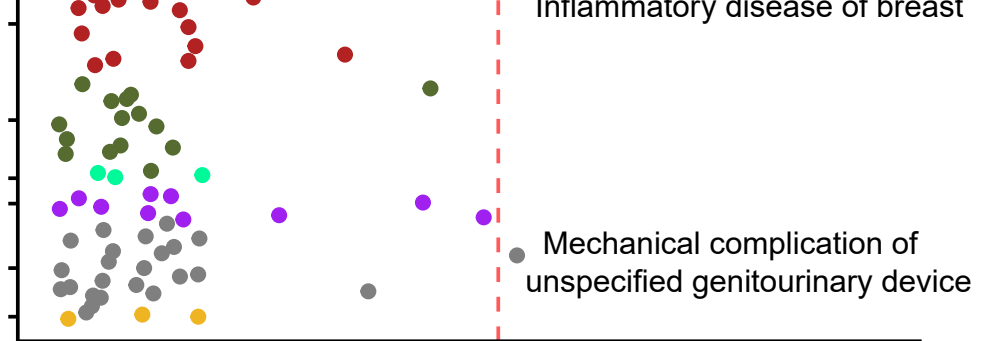

